\title{
Removal of Zirconium (Zr) from Aqueous Solution by Polymer Enhanced Ultrafiltration
}

\author{
O. A Dündar \& Ö. Arar \\ Faculty of Science, Department of Chemistry, Ege University, 35040, İzmir, Turkey \\ Submitted: 5/2/2021. Revised edition: 6/4/2021. Accepted: 7/4/2021. Available online: 15/7/2021
}

\begin{abstract}
Although the world output of zirconium has been declining, increasing zirconium consumption cannot compete with this situation. For this reason, removal and recovery of zirconium become important. This work is focused on the removal of Zirconium (as $\mathrm{ZrO}_{2}{ }^{2+}$ ) ions from an aqueous solution using polymer-enhanced ultrafiltration (PEUF) techniques with water-soluble Poly (sodium-p-styrene sulfonate, SSS) sorbent. The negatively charged sulfonic acid groups in the polymer interact with positively charged $\mathrm{ZrO}_{2}{ }^{2+}$ cation thereby enabling the efficient removal of $\mathrm{ZrO}_{2}{ }^{2+}$ through ultrafiltration. The effect of polymer: zirconium mole ratio, initial solution $\mathrm{pH}$, and the presence of interfering ions on the removal of zirconium was investigated. The obtained results demonstrated that $\mathrm{ZrO}_{2}{ }^{2+}$ can be removed from the aqueous solution by the PEUF technique with more than $99 \%$ efficiency at $\mathrm{pH} \geq 2$ using polymer: $\mathrm{Zr}$ molar ratio of 5:1. The presence of interfering ions did not affect the percent removal of $\mathrm{ZrO}_{2}{ }^{2+}$.
\end{abstract}

Keywords: Polymer-enhanced ultrafiltration, Heavy metal removal, Ion Exchange, water treatment, Zirconium

\subsection{INTRODUCTION}

Zirconium ( $\mathrm{Zr})$ is widely distributed in the earth's crust. It is a significant material for nuclear energy application due to its high transparency to neutrons. It is widely used in industry as secondary metal as it has outstanding chemical, thermal and optical properties [1-3]. "The recovery and purification of nuclear-grade zirconium from spent nuclear fuel cladding have been of great interest due to vast economic and environmental benefits, which result in $\sim \$ 40$ million/year due to the high cost of nuclear-grade zirconium and nuclear waste disposal savings" [4].

Various separation techniques such as biosorption, adsorption, ion exchange, solvent extraction were applied for the removal and recovery of $\mathrm{Zr}$ from aqueous solutions or real samples [2,5-8].

The PEUF is a hybrid process that combines water-soluble polymers and ultrafiltration (UF) techniques. In PEUF, water-soluble polymers have a relatively high molecular weight cutoff (MWCO) that allows the UF membrane to reject. Such polymers also have functional groups to bind ions/small molecules. In this process, unwanted ions/small molecules are first complexed by a polymer to increase their molecular weight with a size larger than the pores of the selected membrane that can be retained whereas permeate water is then purified from the unwanted molecules/ions [9-12].

So far, various metal ions were removed from water by PEUF. For example, Chen et al. [13] used the 
PEUF system to remove $\mathrm{Na}^{+}, \mathrm{K}^{+}, \mathrm{Li}^{+}$, $\mathrm{H}^{+}, \mathrm{Mg}^{2+}, \mathrm{Ca}^{2+}, \mathrm{Sr}^{2+}, \mathrm{Ba}^{2+}, \mathrm{Cu}^{2+}, \mathrm{Pb}^{2+}$, $\mathrm{Co}^{2+}$, and $\mathrm{Ni}^{2+}$ from an aqueous solution by using the SSS a watersoluble polymer. The selectivity sequence of cation affinity for PSS was found to be $\mathrm{Ba}^{2+}>\mathrm{Pb}^{2+}>\mathrm{Sr}^{2+}>\mathrm{Ca}^{2+}>\mathrm{Cu}^{2+}>\mathrm{Co}^{2+}$ $>\mathrm{Ni}^{2+}>\mathrm{Mg}^{2+}>\mathrm{H}^{+}>\mathrm{K}^{+}>\mathrm{Na}^{+}>\mathrm{Li}^{+}$.

The authors also concluded that the concentration of water-soluble polymer in the solution has an important effect on the removal rate and when it was adjusted to $3 \mathrm{~g} / \mathrm{L}$, the $80 \% \mathrm{~Pb}^{2+}$ and $71 \% \mathrm{Cu}^{2+}$ removal were obtained. Hamhami et al. [14] studied the recovery of samarium $\left(\mathrm{Sm}^{3+}\right)$ from aqueous solutions by poly(sodium 4-styrene sulfonate) assisted ultrafiltration. The removal of $\mathrm{Sm}^{3+}$ increased with the increment of polymer concentration in the solution. However further increment in polymer concentration led to a decrease in $\mathrm{Sm}^{3+}$ removal. The authors stated that such decrement caused by several phenomena such as concentration polarization, membrane fouling, osmotic pressure, and precipitation. The solution $\mathrm{pH}$ was also affected the $\mathrm{Sm}^{3+}$ removal rate. At $\mathrm{pH} 1$, about $10 \% \mathrm{Sm}^{3+}$ removed. When the $\mathrm{pH}$ of the solution was increased to 6 , removal of $\mathrm{Sm}^{3+}$ reached $94 \%$.

Rivas and Moreno-Villoslada [15] studied the removal of $\mathrm{Cd}^{2+}$ from an aqueous solution in the presence of $\mathrm{Na}^{+}$ion by PEUF using SSS watersoluble polymer. In the absence of $\mathrm{Na}^{+}$ the complete removal of $\mathrm{Cd}^{2+}$ achieved. In the presence of $0.4 \quad \mathrm{M} \mathrm{NaNO} 3$ removal of $\mathrm{Cd}^{2+}$ decreased.

However, to the best of our knowledge, the removal of $\mathrm{Zr}$ by PEUF has not been reported. This work aims to investigate the optimum conditions for the removal of $\mathrm{Zr}$ by PEUF. In the PEUF procedure, polymer dose (i.e. polymer: target element ratio), initial solution $\mathrm{pH}$, ionic strength (interfering ion), temperature, and applied pressure are the parameters that affect the removal rate [16]. For this purpose, the effect of rpolymer: $\mathrm{Zr}$ ratio, initial solution $\mathrm{pH}$, and interfering ions on the removal of $\mathrm{Zr}$ was investigated.

\subsection{METHODS}

\subsection{Materials}

The water-soluble Poly (sodium-pstyrene sulfonate, SSS) with average MWCO $70 \mathrm{kDa}$ was obtained from Across. Zirconyl chloride octahydrate was obtained from Sigma-Aldrich. Merck Biomax $10 \mathrm{kDa}$ UF disc membrane was used in the experiments. The Amicon UFSC40001 dead-end stirred cell (400 mL capacity) was used in the experiments. The $\mathrm{pH}$ of the solutions was adjusted by using $\mathrm{HCl}$ or $\mathrm{NH}_{3}$ solutions.

\subsection{PEUF Procedure}

The $250 \mathrm{~mL}$ of zirconium containing $(5 \mathrm{mg} / \mathrm{L})$ solution and SSS polymer were stirred in UF cell for the polymer$\mathrm{Zr}$ ion-exchange reaction. After 60 minutes, the cell pressurized by using compressed nitrogen gas with an operating pressure of 1 bar to start the ultrafiltration test. The $100 \mathrm{~mL}$ permeate was collected $(10 \mathrm{~mL}$ x 10 tubes) in permeate probes. The concentration of zirconium in the permeate was measured. The schematic diagram of the process is shown in Figure 1. 


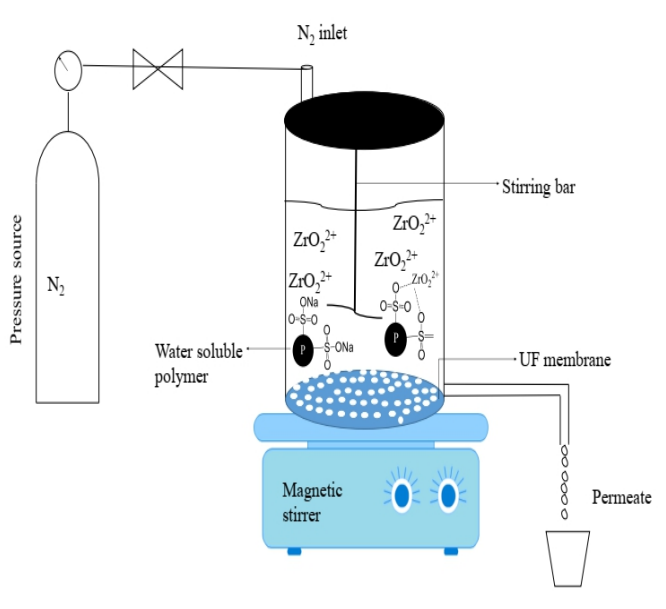

Figure 1 Scheme of the polymerenhanced ultrafiltration, PEUF

The zirconium removal conditions were optimized by changing the PEUF parameters; polymer: $\mathrm{Zr}$ mole ratio $(1: 1,5: 1,10: 1)$, initial solution $\mathrm{pH}(1-$ $4)$, and presence of interfering ions $\left(\mathrm{Na}^{+}, \mathrm{K}^{+}, \mathrm{Ca}^{2+}\right.$ and $\left.\mathrm{Mg}^{2+}\right)$ were optimized.

The $\mathrm{Zr}$ removal, $\mathrm{R}$, (i.e. rejection) was calculated as shown in Equation 1.

$R=\frac{C_{0}-C_{p}}{C_{0}} * 100$

where $\mathrm{C}_{\mathrm{o}}$ and $\mathrm{C}_{\mathrm{p}}$ are concentrations of $\mathrm{ZrO}_{2}{ }^{2+}$ ions in the feed and permeate solutions, respectively.

\subsection{Characterization of SSS}

Fourier transform infrared (FT-IR) measurements $(\mathrm{KBr}$ discs $)$ were recorded in the region of 4000-400 $\mathrm{cm}^{-1}$ on PerkinElmer spectrophotometer.

\subsection{Analyses}

The Alizarin Red S method [17] was used to determine the concentration of $\mathrm{ZrO}_{2}{ }^{2+}$ by UV/VIS spectrophotometer (Agilent, Cary). The $\mathrm{pH}$ of the solution was measured by a $\mathrm{pH}$ meter (FG2 model, Mettler-Toledo).

\subsection{RESULTS AND DISCUSSION}

\subsection{Fourier Transform Infrared Spectroscopy (FTIR)}

Figure 2 displays the FTIR peaks of the polymer used in this experiment. The significant peak at $3434 \mathrm{~cm}^{-1}$ is related to intermolecular hydrogen bonding. The peak at around 2922 $\mathrm{cm}^{-1}$ is the $\mathrm{C}-\mathrm{H}$ vibration. The peaks at $1600-1400 \mathrm{~cm}^{-1}$ are attributed to aromatic ring $\mathrm{C}-\mathrm{H}$ in-plane bending. The main characteristic band of SSS at 1038 and $1008 \mathrm{~cm}^{-1}$ (due to $-\mathrm{SO}_{3} \mathrm{Na}$ group) [18-21].

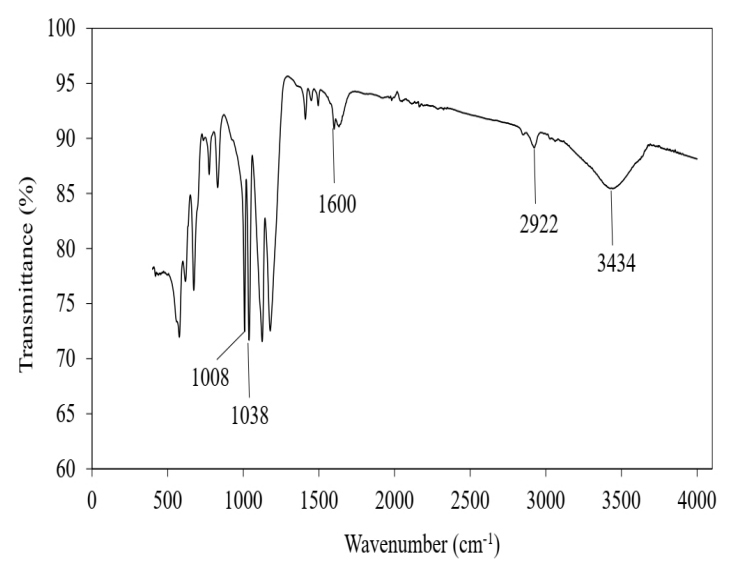

Figure 2 FTIR spectra of SSS

The elemental analysis of polymer was carried out by the Leco Truspec Micro CHNS analyser. Results showed that the polymer consists of $35 \%$ carbon, $3.6 \%$ hydrogen and $9.2 \%$ sulphur.

\subsection{Effect of Polymer: $\mathrm{Zr}$ Mole Ratio on the Removal}

The various dose of the polymer was added to $\mathrm{Zr}$ containing solutions (5 $\mathrm{mg}-\mathrm{Zr} / \mathrm{L}, \mathrm{pH}$ 4) before filtration and 
the resulting removal rate is depicted in Figure 3.

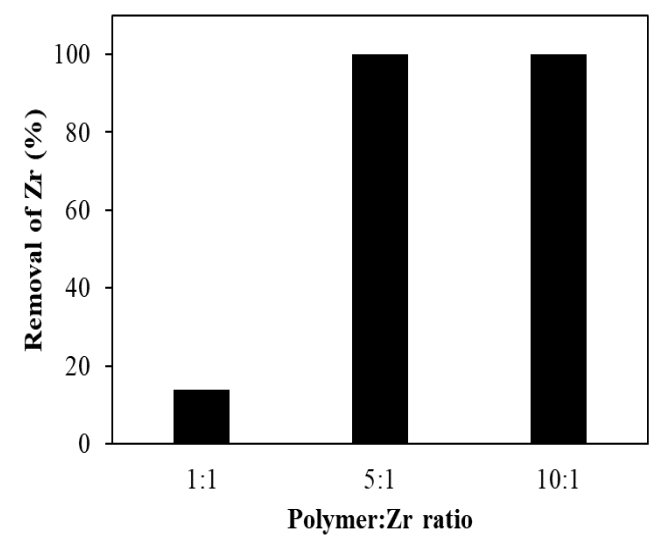

Figure 3 Removal of $\mathrm{Zr}$ as a function of polymer: $\mathrm{Zr}$ ratio

As can be seen from the Figure the percent removal of $\mathrm{Zr}$ increased with an increment on polymer dose. This finding was coincident with the results of Barakat and Schmidt [9] and Sánchez et al. [22]. They also observed that increment in polymer: metal ion ratio improved the removal rate.

The increasing the polymer: $\mathrm{Zr}$ ratio allows more available ionexchange sites and in turn increases the removal efficiency. The ion-exchange reaction between the polymer and $\mathrm{Zr}$ is shown in Equation 2.

$2 \mathrm{R}-\mathrm{SO}_{3}^{-} \mathrm{Na}^{+}+\mathrm{ZrO}_{2}^{2+} \leftrightarrows(\mathrm{R}-$

$\left.\mathrm{SO}_{3}^{-}\right)_{2} \mathrm{ZrO}_{2}^{2+}+2 \mathrm{Na}^{+}$

The optimum polymer: $\mathrm{Zr}$ dose was found to be 5:1 and such ratio was used in the further experiment.

\subsection{Effect of Initial Solution pH on the Removal}

In this series of experiment, initial solution $\mathrm{pH}$ varied from 1 to 4 while $\mathrm{Zr}$ concentration (5 $\mathrm{mg}-\mathrm{Zr} / \mathrm{L}$ ) and polymer: $\mathrm{Zr}$ ratio was adjusted to $5: 1$. The removal rate of $\mathrm{Zr}$ versus different solution $\mathrm{pH}$ is depicted in Figure 4. It is clear from the figure that at $\mathrm{pH} 1$, the SSS polymer could not remove the $\mathrm{Zr}$. When the $\mathrm{pH}$ of the solution was increased, the percent removal of $\mathrm{Zr}$ increased also.

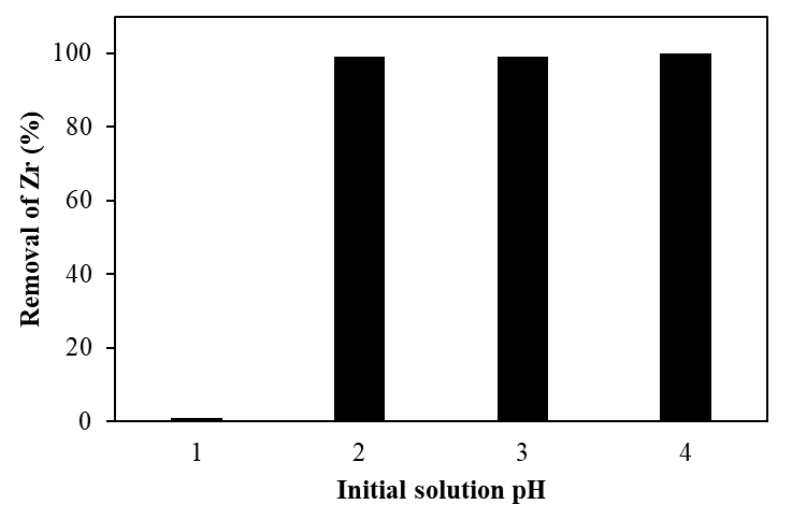

Figure 4 Removal of $\mathrm{Zr}$ as a function of initial solution $\mathrm{pH}$

This behaviour can be explained that there is a competition between $\mathrm{H}^{+}$ and $\mathrm{ZrO}_{2}{ }^{2+}$ ions for the available functional groups of SSS. At $\mathrm{pH} 1$, the concentration of $\mathrm{H}^{+}$is larger than $\mathrm{Zr}$ and this leads to an increase in the ionexchange reaction rate of $\mathrm{H}^{+}$and leads to a low removal rate for $\mathrm{Zr}$ [21]. The optimum $\mathrm{pH}$ range was found as $\geq 2$.

Similar results have been found in the literature for heavy metal removal using SSS polymer. Chen et al. [13] applied PEUF for $\mathrm{Cu}^{2+}$ removal. They found that removal of $\mathrm{Cu}^{2+}$ was $64.7 \%$ at $\mathrm{pH} 2.2$ and it was increased to 96.6 at $\mathrm{pH}$ 7. A much the same trend was observed for the removal of $\mathrm{Sm}^{3+}$ ion [14].

\subsection{Effect of Interfering Ions on the Removal}

The interferences of ions were determined at $\mathrm{pH} 4$ with polymer: $\mathrm{Zr}$ ratio 5:1. The concentration of $\mathrm{Zr}$ was adjusted as $5 \mathrm{mg} / \mathrm{L}$ and obtained results summarized in Table 1. 
Table 1 Effect of interfering ions on the removal of $\mathrm{Zr}$

\begin{tabular}{|l|c|l|}
\hline & $\begin{array}{l}\text { The } \\
\text { concentration } \\
\text { of interfering } \\
\text { ion }(\mathbf{m g} / \mathbf{L})\end{array}$ & $\begin{array}{l}\text { Removal } \\
\text { of } \mathbf{Z r} \mathbf{( \% )}\end{array}$ \\
ion & 5 & $>99$ \\
\hline $\mathrm{Na}^{+}$ & 5 & $>99$ \\
\hline $\mathrm{K}^{+}$ & 5 & $>99$ \\
\hline $\mathrm{Ca}^{2+}$ & 5 & $>99$ \\
\hline $\mathrm{Mg}^{2+}$ & 5 \\
\hline
\end{tabular}

It is clear from Table 1 that; the removal rate was not affected at a low concentration of interfering ions.

Similar findings were reported by Verbych et al. [23]. They stated that at low concentration of $\mathrm{Na}^{+}$and $\mathrm{Ca}^{2+}$ in the solution removal of $\mathrm{Cu}^{2+}$ was almost constant, when the $\mathrm{Na}^{+}$and $\mathrm{Ca}^{2+}$ in the solution 400 times higher than the $\mathrm{Cu}^{2+}$ concentration, the removal rate of $\mathrm{Cu}^{2+}$ decreased.

Lam et al. [24] investigated the effect of $\mathrm{Na}^{+}$on $\mathrm{Ni}^{2+}$ removal. The authors concluded that the presence of $2 \times 10^{-1} \mathrm{M} \mathrm{Na}^{+}, \mathrm{Ni}^{2+}$ removal tended towards zero.

\subsection{CONCLUSION}

The water-soluble SSS polymer was tested for the removal of $\mathrm{Zr}$ with PEUF. The optimum conditions for the $\mathrm{Zr}$ removal were found as polymer $\mathrm{Zr}$ : ratio $5: 1$ and $\mathrm{pH} \geq 2$. The presence of interfering ions at low concentrations did not affect the removal rate.

In a conclusion, PEUF may be an alternative method for the removal of $\mathrm{Zr}$ from solutions.

\section{ACKNOWLEDGEMENT}

This study was supported by The Scientific and Technological Research Council of Turkey, TUBITAK (Program code: 2209).

\section{REFERENCES}

[1] K. Akhtar, M. W. Akhtar, A. M. Khalid. 2008. Removal and Recovery of Zirconium from Its Aqueous Solution by Candida Tropicalis. J. Hazard. Mater. 156: 108-117.

[2] A. Hanif, H. N. Bhatti, M. A. Hanif. 2015. Removal of Zirconium from Aqueous Solution by Ganoderma Lucidum: Biosorption and Bioremediation Studies, Desalin. Water Treat. 53: 195205.

[3] H. Faghihian, M. Kabiri-Tadi. 2010. Removal of Zirconium from Aqueous Solution by Modified Clinoptilolite. $J$. Hazard. Mater. 178: 66-73.

[4] R. Borjas Nevarez, B. McNamara, F. Poineau. 2021. Recovery of Zirconium from Zircaloys Using a Hydrochlorination Process. Nucl. Technol. 207: 263-269

[5] M. Abd El-Magied, W. Salem, A. Daher, E. Elshehy. 2018. Fabrication of Silica Microspheres (HB/A@SI-MNS) for Hafnium and Zirconium Recovery from Zirconyl Leach Liquor. Colloids Interfaces. 2: 14.

[6] I. Sato, H. Kudo, S. Tsuda. 2011. Removal Efficiency of Water Purifier and Adsorbent for Iodine, Cesium, Strontium, Barium and Zirconium in Drinking Water. J. Toxicol. Sci. 36: 829-834.

[7] M. Smolik, A. Jakóbik-Kolon, M. Porański. 2009. Separation of Zirconium and Hafnium using Diphonix ${ }^{\circledR} \quad$ Chelating Ion-exchange Resin. Hydrometallurgy. 95: 350-353.

[8] F. L. Moore. 1956. Separation of Zirconium from Other 
Elements by Liquid-liquid Extraction. Anal. Chem. 28: 997-1001.

[9] M. A. Barakat, E. Schmidt. 2010. Polymer-enhanced Ultrafiltration Process for Heavy Metals Removal from Industrial Wastewater. Desalination. 256: 90-93.

[10] O. D. Kochkodan, V. M. Kochkodan, V. K. Sharma. 2018. Removal of $\mathrm{Cu}(\mathrm{II})$ in Water by Polymer Enhanced Ultrafiltration: Influence of Polymer Nature and $\mathrm{pH}$. $J$. Environ. Sci. Heal. Part A. 53: 33-38.

[11] J. Sánchez, B. Butter, B. L. Rivas. 2020. Biopolymers Applied to Remove Metal Ions through Ultrafiltration a Review. J. Chil. Chem. Soc. 65: 5004-5010.

[12] M. F. Hamid, N. Yusof, N. M. Ismail, M. A. Azali. 2020. Role of Membrane Surface Charge and ComplexationUltrafiltration for Heavy Metals Removal: A Mini Review. $J$. Appl. Membr. Sci. Technol. 24: 39-49.

[13] M. Chen, K. Shafer-Peltier, S. J. Randtke, E. Peltier. 2018. Competitive Association of Cations with Poly(sodium 4styrenesulfonate) (PSS) and Heavy Metal Removal from Water by PSS-assisted Ultrafiltration. Chem. Eng. J. 344: 155-164.

[14] M. Hammami, D. J. Ennigrou, K. H. Naifer, M. Ferid. 2016. Recovery of Samarium (III) from Aqueous Solutions by Poly(sodium 4-styrenesulfonate) Assisted-ultrafiltration. Environ. Prog. Sustain. Energy. 35: 1091-1097.

[15] B. L. Rivas, I. MorenoVilloslada. 1998. Binding of
$\mathrm{Cd}^{2+}$ and $\mathrm{Na}^{+}$Ions by

Poly(sodium 4-styrenesulfonate) Analyzed by Ultrafiltration and Its Relation with the Counterion Condensation Theory. J. Phys. Chem. B. 102: 6994-6999.

[16] Y. Huang, X. Feng. 2019. Polymer-enhanced

Ultrafiltration: Fundamentals, Applications and Recent Developments. J. Memb. Sci. 586: 53-83.

[17] Z. Marczenko, M. Balcerzak. $2000 . \quad$ Separation,

Preconcentration and Spectrophotometry in Inorganic Analysis. 1st Edition. Elsevier. 475-476.

[18] S. Khan, M. Ul-Islam, W. A. Khattak, M. W. Ullah, J. K. Park. 2015. Bacterial Cellulose-poly $(3,4-$ ethylenedioxythiophene)Poly(styrenesulfonate)

Composites for Optoelectronic Applications. Carbohydr. Polym. 127: 86-93.

[19] T. H. Tran, H. Okabe, Y. Hidaka, K. Hara. 2017. Removal of Metal Ions from Aqueous Solutions using Carboxymethyl

Cellulose/sodium Styrene Sulfonate Gels Prepared by Radiation Grafting. Carbohydr. Polym. 157: 335-343.

[20] Z. R. Hinedi. 1993. Chemisorption of Benzene on $\mathrm{Cu}$-Montmorillonite as Characterized by FTIR and ${ }^{13} \mathrm{C}$ MAS NMR. Clays Clay Miner. 41: 87-94.

[21] Ö. Arar. 2020. Co-precipitative Preparation of a Sulfonated Cellulose-magnetite Hybrid Sorbent for the Removal of $\mathrm{Cu}^{2+}$ Ions. Anal. Sci. 36: 81-86.

[22] J. Sánchez, C. Espinosa, F. Pooch, H. Tenhu, G. del C. 
Pizarro, D. P. Oyarzún. 2018. Poly(N,N-dimethylaminoethyl methacrylate) for Removing Chromium (VI) through Polymer-enhanced

Ultrafiltration Technique. React. Funct. Polym. 127: 67-73.

[23] S. Verbych, M. Bryk, M. Zaichenko. 2006. Water Treatment by Enhanced
Ultrafiltration. Desalination. 198: 295-302.

[24] B. Lam, S. Déon, N. MorinCrini, G. Crini, P. Fievet. 2018. Polymer-enhanced

Ultrafiltration for Heavy Metal Removal: Influence of Chitosan and Carboxymethyl Cellulose on Filtration Performances. $J$. Clean. Prod. 171: 927-933. 